\title{
Income, Employment and Saving Patterns of Migrant Women Workers in the Construction Industry
}

\author{
A. Govindharaju*
}

Assistant Professor, Department of Economics, Kamaraj College, Thoothukudi - 628003, Tamil Nadu, India

\begin{abstract}
The research paper is based on income, employment and saving patterns of internal migrant women workers in the construction industry, with special reference to Coimbatore city of Tamil Nadu state in India. The women workers face several problems such as wage discrimination, sexual harassment and poor sanitation in the study area. Sanitation is one of the most environment quality issues linked with population growth. Access to bathroom and restroom facilities is strong indicators. In the study, it was found that 82.4 percent of the construction workers suffer from this problem. The main objective of the study is socio-economic status, income, employment and saving patterns. The study is based on primary data collected using a pre-tested interview schedule. As the information of migrant women workers in the construction sector is not known, 100 migrant women workers were approached as respondents from each of the five zones of Coimbatore City, based on convenient sampling method. But for want of complete set of information, the response of 22 respondents was dropped and the sample size stood at 478. The study reveals that migrant women workers were working on an average five days a week and eight hours a day. In the case of current wage per day, the average wage was found to be Rs. 391. The same was Rs. 132.24 per day at their native place (before migration). On an average, migrant woman workers are saving Rs. 844.87 per month. The wage level of the migrant women workers before the migration was very low compared to the prevailing wage rate of the migrated locality. The lower wage rate in the native place was the reason for women workers to opt for migration for getting higher wage rate. Hence, the wage rate is the dominant factor responsible for the migration of women workers.
\end{abstract}

Keywords: Income, Employment, Migrant Women Workers, Saving Pattern, Socio-Economic Status

\section{Introduction}

Migration is considered as an alternate strategy of sustenance for livelihood by a large number of families in general and poor families in particular. Poor people migrate to the booming intermediate cities as well as industrial centre's in search of employment either due to push factors or due to pull factors. Thus, migration and urbanization have become essential components of economic development and social and political organization. Migration can be of two parts: one is international migration. The other one is internal migration. International migration is migration across the countries of the world. Internal migration deals with migration within the national boundary.

According to the 2011 Census of India, more than 69 percent of India's 1.21 billion people live in rural areas. The country then witnessed rapid urbanization. The cities of Mumbai, Delhi and Kolkata were world's top ten most jam-packed urban areas. They have been among 25 of 100 fastest-growing cities worldwide. A significant source of this growth is rural-to-urban migration. As an increasing number of people do not find sufficient economic opportunities in rural areas.

*Email: govint.inr@gmail.com 
According to 2011 census data, India's urban population has grown faster than its rural population. This is the first time such a trend is seen. The northern states of Uttar Pradesh, Rajasthan, Madhya Pradesh, Chhattisgarh and Bihar had highest percentages of rural populations. These states are the largest migrant-sending ones. All the states show very low social-economic developments. According to Asian Population Study, 90 percent of labourers in the construction industry are found to be internal migrants (Rameez \& Divya, 2014). However, micro-surveys suggest that most of the migrants are between ages of 16 and 40 years. This is particularly so among semi-permanent and temporary migrants. And, most of the labour migrants are employed in a few key subsectors. This includes construction, domestic work, textile and brick manufacturing, transportation, mining and quarrying and agriculture.

It is in this context, the present study has been conducted with the objectives of: 1 . studying the socio-economic background of internal migrant women construction workers, and 2. estimating the income earned, spending patterns and the determinants of remittance of the migrant women workers in the construction industry.

\section{Review of Literature}

Ghaffari and Singh (2000) attempted to identify the imported variable which was responsible for the in-migration and out-migration in the country of Iran. The research study based on ordinary least square model was used to identify the factors which are responsible for in-migration and out-migration. The study found that the housing facilities and related amenities in the destination were the major pull factors which attracted the migrants. The push factors which resulted in outmigration were in the low percentage of irrigated land and the solid reduction of employment opportunity in the study area.

Fielden, et al. (2000) identified the barriers preventing women's entry in the construction industry. The subsequent of barriers faced by those working within the construction industry were also identified. The study found that the barriers arise from a number of sources. This includes the construction industry images, career knowledge among children and adults and male dominated course, recruitment practice and procedure, etc.

Michael (2005) studied remittance, consumption and saving patterns of Mexican migrant workers in the United States of America. The conclusion was that the migrant's remittance and saving behavior of responsive to the relative rate of returns on the savings of migrant workers as well as households at home, i.e., migrant worker's remittance has been more and saving level has been less when the household's rate of return on saving rises or the migrants returns falls.

The study by Regassa and Yusufe (2007) documented the factors that led to migration among 1258 respondents of Southern Ethiopia. The study was based on multivariate analysis. It found that the rural out-migration in Southern Ethiopia was related to economic as well as non-economic factors like shortage of land, food insecurity, and household size pressure, educational and religious status, etc.

Milligan and Bohara (2007) analyzed the effects of remittance income on child welfare in Nepal in terms of its effect on child education attainment and child labour. The study found both remittance and non-remittance income have significantly contributed to child welfare. However, the welfare effect of remittance income was found to be significantly less when compared to the effect of income from other sources.

Imran, et al. (2013) explore the socio-economic determinants of rural-urban migration in urban setting by conducting a study in Sargodha city. 120 respondents were taken up as samples equally (40 from each colony) from three randomly selected localities. They were Satellite Town, Farooq Colony and Old Civil Line. The descriptive analysis shows that inappropriate educational, health and recreational facilities, poor infrastructure and insufficient economic opportunities are the main factors that motivate an individual and families to migrate from rural to urban areas. It is concluded that, numerous studies are conducted to investigate the determinants of migration from rural areas in the context of the migration at different levels, 
i.e., individual level and family level. The empirics of these studies show different factors of migration.

Neetha (2014) studied the adoption of domestic work by women migrants in the city of Delhi. The study was based on the survey among 465 women migrants. It revealed that women migrated with the awareness of the domestic jobs available in the city, higher wages and the working conditions. It confirms that almost all the women domestic workers had some prior knowledge of employment possibility as domestic help before migrating to Delhi. This had substantial role in the decision to migrate. Domestic work was also no longer seen as a bridging occupation permitting entry to a location which boasted of greater potential or social and economic mobility. It was found that the conditions of work in domestic service are deplorable. This is due to long working hours, low pay and absence of job security. The study highlighted that migration for domestic service is largely a female driven phenomenon. This was primarily due to preference of women for employment.
Belwal and Belwal (2014) made an attempt to study the impact of out-migration in rural areas of Uttarkhand. A survey among 675 migrant respondents was conducted. It was found that there was an increasing trend of rural out-migration in recent years. The study predicted the impact of rural out-migration. Due to out-migration, Uttarhand has to face the scarcity of creative, energetic and able youth in urban areas. Also, the excess of workforce has generated the problem of unemployment and the exploitation of labour. It was concluded that high rate of rural out-migration poses threats from the socio-economic and demographic point of view also.

\section{Methodology}

\subsection{Data and Sampling}

The study was based on primary data collected. A pretested interview schedule was used for the purpose. As the information regarding size of migrant women workers in the construction sector is not known for the study, 100 migrant women workers were approached as

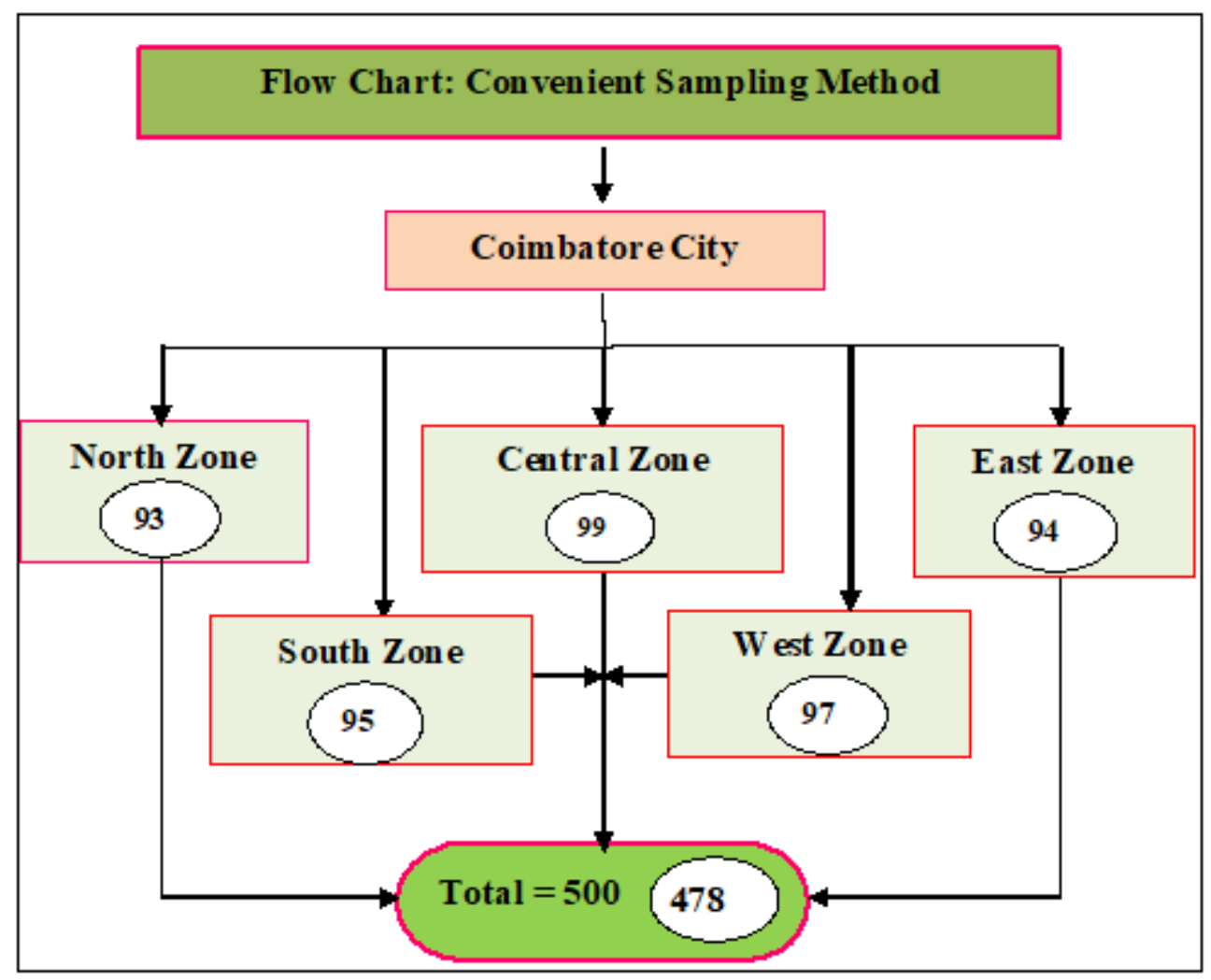

Figure 1. Selection of sample. 
respondents from each of the five zones of Coimbatore city based on the convenient sampling method. For want of complete set of information, the responses of 22 respondents were dropped and the sample size stood at 478 (i.e., 99 respondents from central zone, 97 from west zone, 95 from south zone, 94 from east zone and 93 from north zone) (Figure 1).

\subsection{Estimation Tools Used in the Study}

Statistical tools like average, percentage, regression and scaling techniques were used to analyze the data. In order to study the relationship among living conditions, working conditions, hours of work, income and socio-economic factors, Chi-Square test was used.

\subsection{Scope of the Research}

The research study is to understand the socioeconomic background of the internal migrant women construction workers, the nature of migration, living and working conditions, and estimate the income, expenditure, spending and saving pattern of migrant women construction workers.

\section{Results and Discussions}

Table 1 reveals that out of 478 migrant women workers 91.6 percent hail from villages (rural areas) while eight percent are from urban areas. Poor people, who did not get work in the rural areas, migrate to the towns to earn their livelihood. Therefore, the majority of the

Table 1. Migration stream

\begin{tabular}{|l|l|c|c|}
\hline SI. No. & Stream & Respondents & Percent \\
\hline 1. & Rural to Urban & 438 & 91.6 \\
\hline 2. & Urban to Urban & 40 & 08.4 \\
\hline & Total & 478 & 100.00 \\
\hline
\end{tabular}

Source: Primary Data

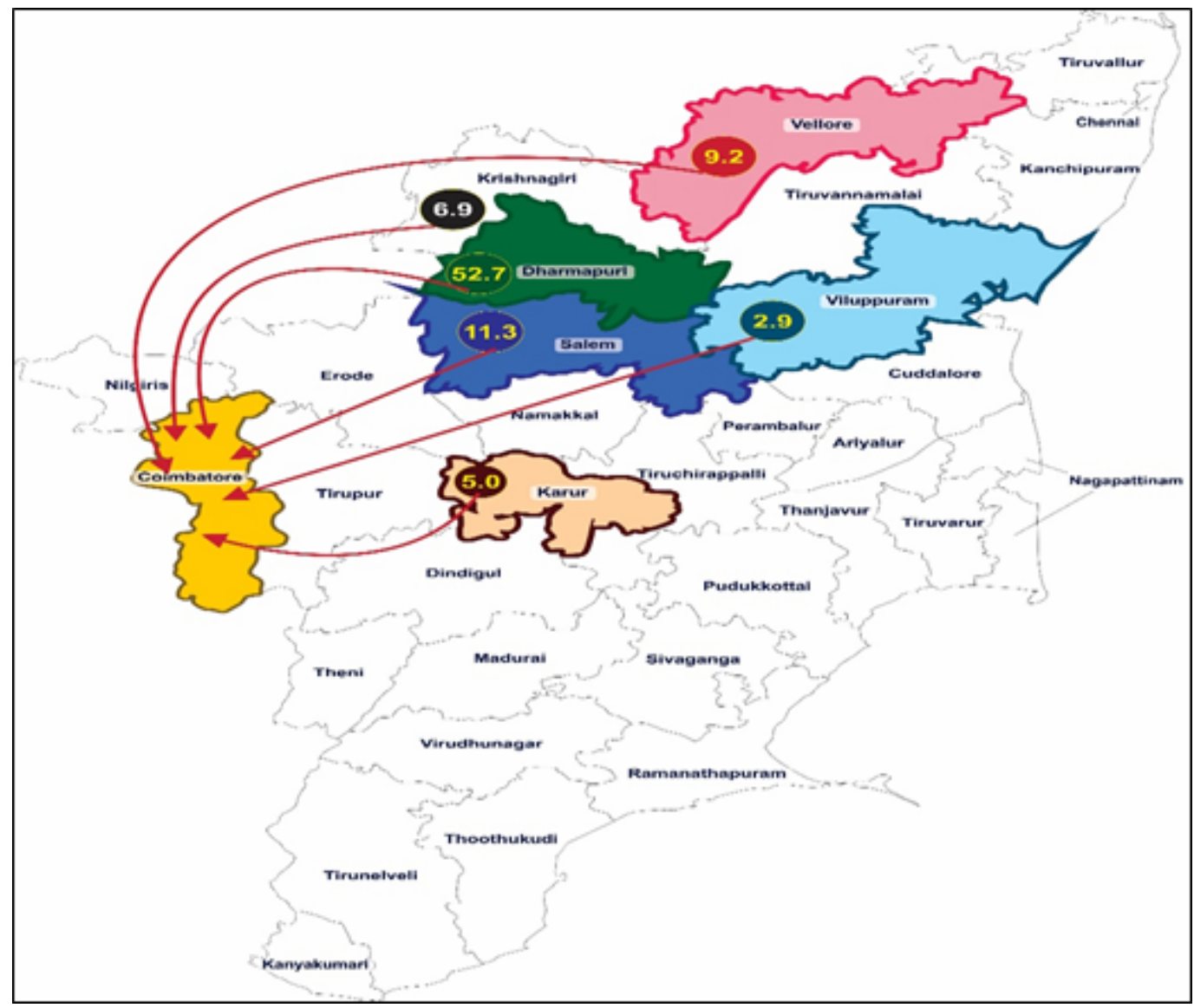

Figure 2. Internal migration from other districts to Coimbatore. 
migrant workers found in the construction industry have migrated from rural areas. Nearly 53 percent of migrant women workers belong to Dharmapuri district.

In case of migration from rural areas, it can be understood that the push factors were strong for people to migrate. But in the case of urban to urban migration, more than push factors, pull factors would have been stronger.

Figure 2 shows that the migrant women workers were mostly from different districts of Tamil Nadu. Amajority of the migrant women workers were from Dharmapuri (52.7 percent), followed by Salem (11.3 percent), Vellore (nine percent), Krishnagiri (ten percent), Karur (five percent), Vilupuram and Thiruvannamalai (three percent) and other districts (nine percent). A very small proportion of respondents represent Vilupuram and Thiruvannamalai three percent. Among the women migrant construction workers, an overwhelming majority report their place of origin to be Dharmapuri (52.7 percent), followed by Salem (11.3 percent).

\subsection{Wages and Earnings}

Different rates of wages is paid to the different types of construction workers, and consequently, their earnings from this sector depend on a multitude of factors that include: i) The instability of demand and fluctuation in the market, ii) Segmented groups of different labour types, iii) Seasonal nature of employment, iv) Invisibility of principal employer-employee relations, v) Unregulated nature of the contractual relations, vi) The control and dominance of labour contractors in the supply of labour, (vii) Vulnerability of the worker cased by his/her economic conditions, and viii) Seasonal availability of employment and workers mobility between sectors or areas, etc.

Construction workers have to work for long hours to meet their basic needs. After doing work for longer period on site, these women workers have to work in their homes also. Table 2 shows that most of the migrant women workers (93.3 percent) work for seven hours, whereas five percent of the women workers work for eight hours, and finally, two percent of the workers work for nine hours. Those who are working for nine hours are those who go to work along with
Table 2. Details of working hours, working days and wage

\begin{tabular}{|c|c|c|c|}
\hline SI. No. & Working Hours/per Day & Respondents & Percent \\
\hline 1. & $7 \mathrm{Hrs}$ & 446 & 93.4 \\
\hline 2. & $8 \mathrm{Hrs}$ & 23 & 04.8 \\
\hline \multirow[t]{2}{*}{3.} & $9 \mathrm{Hrs}$ & 08 & 01.8 \\
\hline & Total & 478 & 100.00 \\
\hline SI. No. & \multicolumn{2}{|c|}{ Working Days (per Week) } & Percent \\
\hline 1 & 3 & 25 & 05.2 \\
\hline 2 & 4 & 121 & 25.3 \\
\hline 3 & 5 & 140 & 29.3 \\
\hline \multirow[t]{2}{*}{4} & 6 & 192 & 40.2 \\
\hline & Total & 478 & 100.00 \\
\hline SI. No. & \multicolumn{2}{|c|}{ Wage Rate per Day (in Rs.) } & Percent \\
\hline 1 & Below 300 & 13 & 02.8 \\
\hline 2 & $301-350$ & 38 & 07.9 \\
\hline 3 & $351-400$ & 415 & 86.8 \\
\hline \multirow[t]{2}{*}{4} & Above 400 & 12 & 02.5 \\
\hline & Total & 478 & 100.00 \\
\hline
\end{tabular}

Source: Primary data

their life partners. As men are paid more wages, they are expected to stay for longer hours. So are their counterparts. The majority of women workers work for seven hours in a day. However, in the matter of consistency in employment, they face uncertainty in getting the work daily.

According to Labour Act, the legal hours of work are only eight hours, but, due to the heavy economic necessity, these workers are forced to work for long hours. About 40 percent of the migrant women workers got six days work per week and 29.3 percent of the migrants got five days workper week followed by 25.4 percent with four days of work a week. Six percent of the migrant women workers got only three days work per week. Sand scarcity has severely impacted the construction industry in the district of Coimbatore. It is a strong indication of joblessness of masons and labourers.

Which the aim of arresting the economic condition of the women workers, they were grouped into four 
categories based on their daily earnings, i.e., below Rs. 300, Rs. 301-350, Rs. 351- 400 and above Rs. 400 per day. Most of the women workers, i.e., 86.2 percent of the workers, were earning Rs. 351-400 per day, followed by eight percent of the women workers earning Rs. 301-350 per day. Only three percent of the migrant women construction workers earn above Rs. 400 per day, and remaining three percent of the women workers earn below Rs. 300 per day. According to Department of Labour, Government of Tamil Nadu, in September 2018, the minimum wages for unskilled labourers in the construction industry was Rs. 265.65 per day (Ministry of Labour and Employment, Govt. of India, 2018). The wages earned after migration is compared with that earned before migration, It could be concluded that there is a statistical increase in their wage, as nearly 90 percent of paid more than Rs. 350 per day, whereas, before migration 97 percent of there were getting less than Rs. 250 per day.

Table 3 shows that saving habit of the migrant women workers is an ideal indicator to understand their financial status. It is to be noted that, out of the total workers taken, 281 respondents (58.8 percent) have the habit of saving from their income. As many as 41.2 percent migrant women workers did not have the habit of saving. Income is an important factor of saving. The present study reveals that 86.1 percent of the women workers who have saving habits save below Rs. 1,000

Table 3. Saving mode by the respondents

\begin{tabular}{|c|c|c|c|}
\hline SI. No. & Do you Save? & Respondents & Percent \\
\hline 1. & Yes & 281 & 58.8 \\
\hline \multirow[t]{2}{*}{2.} & No & 197 & 41.2 \\
\hline & Total & 478 & 100.00 \\
\hline \multicolumn{4}{|c|}{ Amount of Saving per Month (in Rs.') } \\
\hline 1. & Up to 1,000 & 242 & 86.1 \\
\hline 2. & $1001-2,000$ & 37 & 13.2 \\
\hline \multirow[t]{2}{*}{3.} & Above 2,000 & 02 & 0.7 \\
\hline & Total & 281 & 100.00 \\
\hline
\end{tabular}

Source: Primary data per month, followed by 13.2 percent with a saving of Rs. 1,001-2,000 per month. Remaining 0.7 percent of the migrant women construction workers save above Rs. 2,000 per month. Most of the women, (86 percent) save up to Rs. 1,000 per month Table 4.

Descriptive analysis of employment related to variable reveals that, on an average, migrant woman in construction sector work for seven hours a day. The working days per week were five days. This indicates that migrant women workers were working on an average five days a week and seven hours a day. In the case of current wage per day, the average wage was found to be Rs. 391.98 with a median of Rs. 400.00 per day. The same was Rs. 132.24 per day at their native place. Regarding the average wage of their husband's wage of the migrant women workers, it was found to be Rs. 705.15 per day with a median of Rs. 750 per day. The average value of saving was found to be Rs. 844.87 per month. In the case of remittance the average amount of remittance of the respondents per month were found to be Rs. 4199.78 per month. The wage level of the migrant women workers before migrate the locality was very low compared to the prevailing wage rate of the migrated locality. The lower wage rate in the native place forced the women workers to opt for work with higher wage rate. Hence, the wage rate is the dominant factor responsible for the migrant women workers.

Table 4. Descriptive analysis of employment related variables of the migrant women workers

\begin{tabular}{lccccc}
\hline Sources & Sum & Mean & Median & $\begin{array}{c}\text { Std. } \\
\text { Deviation }\end{array}$ & N \\
\hline $\begin{array}{l}\text { Working } \\
\text { Hours* }\end{array}$ & $3,862.00$ & 7.0795 & 8.0000 & .33327 & 478 \\
$\begin{array}{l}\text { Working } \\
\text { Days }\end{array}$ & $2,411.00$ & 5.0439 & 5.0000 & .92946 & 478 \\
$\begin{array}{l}\text { Current } \\
\text { Wage }\end{array}$ & $1,87,370.00$ & 391.9874 & 400.0000 & 24.4258 & 478 \\
$\begin{array}{l}\text { Wage (Native } \\
\text { place) Before }\end{array}$ & $63,215.00$ & 132.2490 & 150.0000 & 81.2412 & 478 \\
$\begin{array}{l}\text { Migration* } \\
\text { Husband's }\end{array}$ & $2,89,100.00$ & 705.1220 & 750.0000 & 79.8296 & 416 \\
$\begin{array}{l}\text { Wage } \\
\text { Saving }\end{array}$ & $2,39,100.00$ & 844.8763 & 500.0000 & 59.4725 & 281 \\
$\begin{array}{l}\text { Remittance } \\
\star \star *\end{array}$ & $16,08,500$ & $4,199.7389$ & 5000.0000 & 98.6750 & 383 \\
\hline
\end{tabular}

Source: Primary Data, ${ }^{*}$ - per day, ${ }^{\star *}$ - per week, ${ }^{\star \star *}$ - per month. 
Table 5. Significance of difference in various aspects of migrant women workers

\begin{tabular}{clccc}
\hline $\begin{array}{r}\text { SI. } \\
\text { No. }\end{array}$ & Variables & $\begin{array}{c}\text { Chi-Square } \\
\text { Values }\end{array}$ & $\begin{array}{c}\text { Significance } \\
\text { Values }\end{array}$ & $\begin{array}{c}\text { Null } \\
\text { Hypothesis }\end{array}$ \\
\hline 1. & Age & 30.90 & .002 & Rejected \\
2. & Education & 19.37 & .081 & Accept \\
3. & Social Category & 88.19 & .000 & Rejected \\
4. & Nature of Work & 10.16 & .253 & Accept \\
5. & District of & 133.85 & .000 & Rejected \\
& Migrants & & & \\
6. & Working & 27.18 & .007 & Rejected \\
& Experience & & & \\
7. & Type of House & 114.84 & .000 & Rejected \\
8. & House Rent & 159.04 & .000 & Rejected \\
9. & Drinking Water & 62.62 & .000 & Rejected \\
\hline
\end{tabular}

Source: Primary Data

Hypothesis: There are significant differences in various socio-economic aspects among the migrant women construction workers.

The result of the Chi - Square test reveals as seen in the Table 5 that education and the nature of work, where the null hypothesis proves to be accepted indicates that there is no significant difference between in education and nature of work of construction workers. However, in all other aspects there is a significant difference among them in terms of other socio-economic attributes.

\section{Conclusion, Policy Implications and Direction for Future Study}

It is concluded that among women workers a vast majority fall in the middle age group. The Most Backward Caste (MBC) and Schedule Tribe (ST) categories of women workers with Hindu Religion were found to be more in the sector. The majority of the migrant women construction workers in the study area were married. This supports the argument that marriage is one of the most important reasons behind migration, as after marriage women migrate along with their spouse for want of jobs. It was found that 68 percent of the migrants did not complete their primary level of education. Migrant women workers were working on an average five days a week and eight hours a day. In the case of current wage per day the average wage was found to be Rs. 391.98. The same was Rs. 132.24 per day at their native place (before migration). On average migrant women workers are saving Rs. 844.87 per month. The wage level of the migrant women workers before the migration was very low compared to the prevailing wage rate of the migrated locality. The lower wage rate in the native place was the reason for women workers to opt for migration for getting higher wage rate. Hence the wage rate is the dominant factor responsible for the migration of women workers.

From the study, it is understood that the migrant women workers are ignorant of labour laws and saving patterns. Counseling programs must be conducted to create awareness among them on labour laws and the necessity to save a part of their earnings. The government must evolve ways to implement a 'Contributory Passion Scheme' (CPS). The migrant women workers can be motivated to save for their future. Further, awareness programs among the public to safeguard the welfare of the migrant women workers must be conducted. After all, the contribution of the migrant women workers to the welfare of the society is monumental.

The future studies may focus on a comparative study on rural-urban inflows and outflows of migration. Further, the role of gender in remittances can be seen as a potential factor, but has to be evidenced by the future studies. A study assessing the opportunity cost of migration would provide useful policy directions to the administrative machinery.

\section{References}

Asia-Pacific Migration Report (2015). Migrants Contributions to Development.

Belwal, S. and Belwal, R. (2014). Work-Life Balance, FamilyFriendly Policies and Quality of Work Life Issues: Studying Employers Perspectives of Working Women, Journal of International Women's Studies. 15(1).

Fielden L. Sandra, Marilyn J. Davidson, Andrew W. Gale and Caroline L. Davey (2000). Women in construction: The untapped resource, Construction Management and Economics. 18(1):113-121, ISSN 0144-6193, print ISSN 1466-433X. https://doi.org/10.1080/014461900371004.

Ghaffari, H. and Singh, S. P. (2000). Pull-Push determinants of inter-provincial migration: Iran's case study, Indian Journal of Economics. 81(321):269-275. 
Imran Faisal, Yasir Nawaz, Muhammad Asim and Arshad Hashmi, H. (2013). Socio-Economic determinants of rural migrants in urban setting: A study conducted at City Sargodha, Pakistan, Academic Journal of Interdisciplinary Studies. 2(1):71. https://doi. org/10.5901/ajis.2013.v2n1p71.

Milligan and Mand Bohara, A. (2007). The Effect of Remittances on Child Labor and Child Education in Nepal. See discussions, stats, and author profiles for this publication at: https://www.researchgate.net/publication/33022493.

Michael, A. Quinn (2005). Remittances, savings and relative rates of return, The Journal of Developing Areas. 38(2):1-23. https://doi.org/10.1353/jda.2005.0028.
Neetha, N. (2014). Making of female breadwinners migration and social networking of women domestics in Delhi, Economic and Political Weekly. April 242014.

Rameez, Abbas and Divya, Varma (2014). Emerging pattern of urbanization and contribution of migration in urban growth in India, Asian Population Studies. 5(1): 2-20.

Regassa and Yusufe (2007). Correlates of rural out-migration in Southern Ethiopia, Journal of Social and Economic Development. 9(1):25-37.

United Nations (2016). International Migration Report 2015, Department of Economic and Social Affairs.

World Migration Report 2015, 2016, 2017 and 2018. 